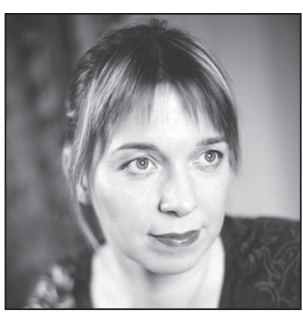

Mari Kelve-Liivsoo

Bachelor's student University of Tartu

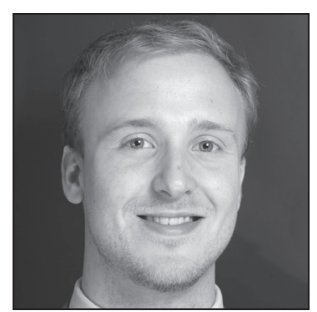

Artur Knjazev

Master's student University of Tartu

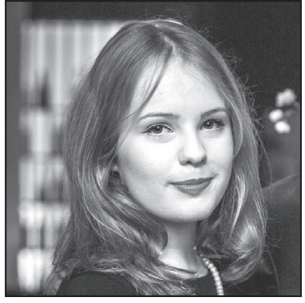

Tea Kookmaa

Master's student

University of Tartu

\title{
Legal Remedies Available to Competitors of Recipients of Unlawful State Aid under Estonian Law
}

\section{Introduction}

This article addresses the issue of breaching the standstill obligation under Article 108 (3) of the Treaty on the Functioning of the European Union (hereinafter 'TFEU') ${ }^{*}$ and the legal remedies possible under Estonian legislation that are available to persons whose rights have been infringed by way of unlawful state aid. The paper focuses mainly on the competitors of the recipient of unlawful state aid.

State aid and its potential recovery is highly topical in Estonia. In April 2014, the European Commission decided to initiate formal investigative procedure in the case of Estonian Air. ${ }^{{ }_{2}}$ The company had benefited from several public interventions over the space of 10 years while only a single capital injection is allowed as restructuring aid. ${ }^{*} 3$ Another example is the Estonian Electricity Market Act, which allows support for producers of energy from renewable sources. ${ }^{*} 4$ This state aid scheme was approved by the European Commission but actually launched before the approval. ${ }^{*} 5$

Pursuant to Article 107 (1) of the TFEU, aid granted by a Member State to undertakings and fulfilling the criteria listed in that article ${ }^{* 6}$ (i.e., state aid) is generally not permissible. State aid may be given or altered only upon prior approval of the European Commission (also 'the Commission'). ${ }^{*} 7$ The Member State concerned shall not put its planned measures into effect until the Commission has reached a final decision on the compatibility of these measures with the internal market. This is referred to as the standstill obligation. ${ }^{*}$ Said obligation is breached where the Member State fails to notify the Commission of state aid or does notify the Commission but fails to wait for a positive decision. The standstill obligation is intended to guarantee that state aid does not take effect before the Commission has had a reasonable period within

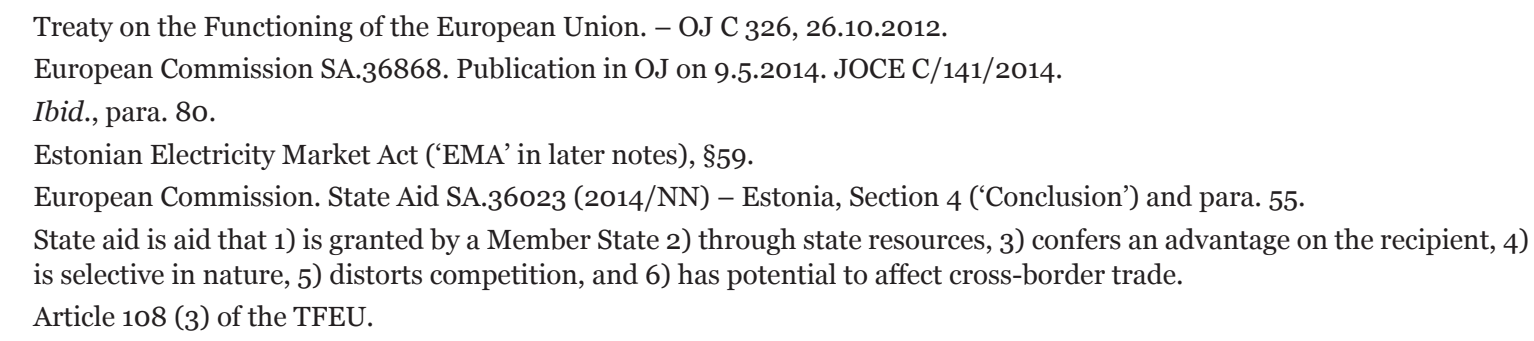


which to check the compatibility of a state aid measure or scheme with the single market and, should it deem this necessary, to initiate the procedure foreseen in Article 108 (2) of the TFEU. ${ }^{*}$ It must be stated, however, that two types of aid are exempted from the notification obligation: aid falling under the de minimis regulation ${ }^{* 10}$ and under the General Block Exemption Regulation ${ }^{* 11}$. These two types of aid are not addressed in the present article.

The beneficiary of unlawful aid gains a competitive advantage that distorts competition in the common market. Even if the Commission later finds the aid compatible with the common market, such distortion is deemed to have been present until the time of the decision by the Commission, which is the only permissible legal basis for disbursing the aid. If this were not the case, Article 108 (3) of the TFEU would not have the impact for which it has been designed. ${ }^{*} 12$

The Commission, when notified of a state aid measure or scheme, takes one of the decisions outlined in the respective procedural regulation. ${ }^{* 13}$ It can record that it has found no state aid ${ }^{* 14}$, that the aid is compatible with the internal market ${ }^{* 15}$, or that there are doubts as to whether the aid is compatible ${ }^{* 16}$. In the last of these cases, the Commission will launch a formal investigative procedure, inviting the Member State to submit comments within a month ${ }^{{ }^{* 17}}$ and issuing a final decision within 18 months ${ }^{{ }^{* 1} 18}$.

A negative decision by the Commission ${ }^{* 19}$ carries severe consequences: the Commission can rule recovery in order, with illegality interest due from the date on which the aid was granted. ${ }^{{ }_{20}}{ }^{20}$ Even if the Commission takes a positive decision, the latter does not remedy the breach of the standstill obligation. ${ }^{{ }_{21}}$

Article 108 (3) of the TFEU has a direct effect and gives rise to rights of individuals ${ }^{{ }^{2} 2}$, such as the competitors of the beneficiary. These are the individuals most adversely affected by the aid measures, because the aid increases the competitiveness of the recipient to the detriment of its competitors. However, there are other possible categories of individuals whose rights are negatively affected by the breach of the standstill obligation, such as taxpayers if the latter pay taxes under an unlawful state aid scheme. ${ }^{{ }^{2} 3}$

The European Court of Justice (or 'ECJ') has clarified that national courts are obliged to safeguard the rights of individuals until the final decision of the Commission is issued. ${ }^{* 24}$ This includes obligation to ensure that the aid does not remain at the free disposal of the recipient during the standstill period. ${ }^{{ }^{2} 25}$ The national law must therefore provide effective legal remedies for the affected individuals to exercise their rights. ${ }^{* 26}$ The article first analyses legal remedies proposed by the ECJ. It then examines Estonian law in terms of availability of these remedies.

9 Case C-368/o4, Transalpine Ölleitung in Österreich $\mathrm{GmbH}$ and Others $v$. Finanzlandesdirektion für Tirol and Others ('Transalpine' in later notes) (2006), ECR I-09957, para. 26.

10 Commission Regulation (EU) No. 1407/2013 of 18 December 2013 on the application of Articles 107 and 108 of the Treaty on the Functioning of the European Union to de minimis aid (24.12.2013). OJ L 352/1.

11 Commission Regulation (EU) No. 651/2014 of 17 June 2014 declaring certain categories of aid compatible with the internal market in application of Articles 107 and 108 of the Treaty (26.6.2014). OJ L 187/1.

12 Case C-199/o6, Centre d'exportation du livre français (CELF) and Ministre de la Culture et de la Communication v. Société internationale de diffusion et d'édition (SIDE) ('CELF' in later notes) (2008), ECR I-00469, para. 40.

13 Council Regulation (EC) No. 659/1999 of 22 March 1999 laying down detailed rules for the application of Article 93 of the EC Treaty (27.3.1999). OJ L 083, P. 0001-0009.

14 Ibid., Article 4 (2).

15 Ibid., Article 4 (3): '[...] the decision not to raise objections [...]'.

16 Ibid., Article 4 (4): 'The decision to initiate the formal investigation procedure [...]'.

17 Ibid.

18 Ibid., Article 7 (6).

19 Ibid., Article 7 (5): '[...] aid is not compatible with the internal market [...]'.

20 Case C-70/72, Commission of the European Communities v. Federal Republic of Germany (1973), ECR 813, para. 13.

$21 \quad C E L F$ (see Note 12), para. 40.

22 Case 120/73, Gebrüder Lorenz GmbH v. Federal Republic of Germany and Land Rheinland-Pfalz (1973), ECR 1471, para. 8; Case C-284/12, Deutsche Lufthansa AG v. Flughafen Frankfurt-Hahn GmbH ('Lufthansa' in later notes) (2013), ECLI:EU:C:2013:755, para. 29.

23 Case C-174/02, Streekgewest Westelijk Noord-Brabant v. Staatssecretaris van Financiën ('Streekgewest' in later notes) (2005), ECLI:EU:C:2005:10, para. 21.

24 Lufthansa (see Note 22), para. 31; Case C-1/09, CELF and Ministre de la Culture et de la Communication (2010), ECR I-2099, para. 30.

25 Lufthansa (see Note 22), para. 31; Case C-1/o9, CELF and Ministre de la Culture et de la Communication (ibid.).

26 Transalpine (see Note 9), para. 45. 


\section{Legal remedies derived from the case law of the ECJ}

\subsection{General considerations}

All undertakings operating in the single market have a right to operate under conditions that are not distorted by unlawful state aid. It must be recalled that EU law recognises the liability only of the aid grantor, not the recipient. ${ }^{* 27}$ State liability was confirmed, inter alia, in the Traghetti case. ${ }^{* 28}$

According to the case law of the $\backslash E C J$, protection of the rights derived from Article 108 (3) of the TFEU is a task of the national courts. ${ }^{*}{ }^{29}$ The national courts' competence and duty is based on that obligation, which has been specified over the decades through ECJ case law.

Claims that are based on violation of Article 108 (3) of the TFEU must be processed in accordance with the relevant national law. In that regard, the ECJ held in the Transalpine case that, since there is no Community legislation on the subject, each Member State must, under its own legal system, designate the courts having jurisdiction and determine the detailed procedural rules governing actions in law intended to safeguard the rights derived for individuals from Community law. ${ }^{*}{ }^{30}$ In doing so, Member States need to respect the principle of equivalence, guaranteeing that those rules are not less favourable than those governing rights originating in domestic law. ${ }^{*}{ }^{11}$ They must also comply with the principle of effectiveness - i.e., not render the exercise of rights conferred by the Community legal order impossible or excessively difficult in practice. ${ }^{*}{ }^{32}$

The case law of the ECJ indicates that national courts' main obligation when facing an unlawful state aid measure is to eliminate the distortion of competition that was caused by the violation of the standstill obligation. ${ }^{*} 33$ In other words, national courts must restore the competitive situation that existed prior to the infringement. ${ }^{*} 34$

\subsection{Recovery of unlawful aid}

The ECJ has consistently held that national courts must, in principle, order the recovery of unlawful aid pursuant to their national law. ${ }^{*} 35$ In cases wherein the Commission has initiated a formal procedure in accordance with the TFEU's Article 108 (2), a national court is competent to order the recovery of the unlawful aid measure and also to order provisional measures so as to safeguard the interests of the parties concerned. ${ }^{*} 6$ A possible and effective provisional measure would be to suspend the implementation of the measure in question or deposit the unlawful sums. ${ }^{*}{ }^{37}$

Another development in the ECJ case law shows that unlawful aid must be recovered along with the illegality interest in respect of the time of unlawfulness. Even in cases of a positive decision, the aid given prior to the decision remains unlawful and the obligation to pay the illegality interest still holds. ${ }^{*} 38$ The national court may ask the Commission for assistance in calculating the amount. ${ }^{*} 9$

27 Case C-39/94, Syndicat Français de l'Express International (SFEI) and Others $v$. La Poste and Others ('SFEI' in later notes) (1996), ECR I-03547, para. 74.

28 Case C-173/o3, Traghettidel Mediterraneo SpAv. Repubblica italiana ('Traghett' in later notes) (2006), ECLI:EU:C:2006:391, paragraphs 41 and 50.

29 Lufthansa (see Note 22), para. 29; SFEI (see Note 20), para. 40; CELF (see Note 12), paragraphs 12 and 14.

30 Transalpine (see Note 9), para. 45.

31 Ibid.

32 Ibid.

33 Case C-275/10, Residex Capital IV CV v. Gemeente Rotterdam (2011), 2011 I-13043, para. 34 ('Residex Capital' in later notes) and the case law cited therein.

34 Ibid., para. 46.

CELF (see Note 12), para. 39; Residex Capital (see Note 33), para. 29.

Lufthansa (see Note 22), para. 43.

Ibid.

CELF (see Note 12), paras 52 and 55 .

39 Commission notice on the enforcement of State aid law by national courts (2009/C 85/o1), para. 36. See also Commission Regulation (EC) 794/2004 on this subject. 
Recovery of aid must be effective and immediate. ${ }^{*} 40$ However, there may be a few exceptional cases in which the unlawful aid cannot be recovered. Firstly, the recipient of unlawful aid may rely on the principle of legitimate expectations in cases wherein a Community authority has caused the recipient to entertain those expectations. ${ }^{*}{ }^{41}$ This would be the case, for example, where the Commission has previously adopted a decision declaring that there is no state aid or that the aid is compatible with the single market. Secondly, the recipient of unlawful aid may rely on the principle of legal certainty if the Commission does not act within 10 years from the time when it learnt of the existence of the aid incompatible with the common market. ${ }^{*} 42$ Thirdly, the Member State may plead that it is absolutely impossible to recover the aid. ${ }^{*} 4$

\subsection{Preventing payment of unlawful aid}

If the unlawful aid has not yet been given, the individual suffering on account of the violation of Article 108 (3) TFEU must have an effective remedy to prevent the rendering of the unlawful aid. This kind of remedy is derived from the general principle that national courts must safeguard individual rights conferred by Article 108 (3) of the TFEU and take all appropriate measures related to the validity of measures giving effect to the aid, recovery of the latter, and possible interim measures. ${ }^{*} 44$

\subsection{Damage claims}

In addition to the recovery obligation arising from the breach of the standstill obligation, the above-mentioned provision may give rise to damage claims. If competitors to the aid beneficiary sustain damages and there is a direct causal link between the breach of Article 108 (3) TFEU and the damage, the injured party has a right to claim damages. ${ }^{*} 45$ The conditions for damage claims are derived from the case law - specifically, the Francovich ${ }^{*} 46$ and Brasserie du Pêcheur ${ }^{*} 47$ cases.

\section{Legal remedies in Estonian administrative law}

\subsection{General considerations}

According to Estonian law, unlawful aid must be recovered along with the illegality interest on the basis of the Commission's or ECJ's decision. ${ }^{*} 48$ The national law does not contain specific legal remedies for dealing with issues of unlawful state aid in circumstances wherein the standstill obligation is breached. However, in public law, the relevant claims can be derived from the State Liability Act"49 (or 'SLA'). A person may also rely on directly applicable provisions of EU law such as those of Article 108 (3) TFEU and the relevant interpretations of the ECJ.

40 Case C-415/03, Commission of the European Communities $v$. Hellenic Republic (also known as 'Olympic Airways') (2005), 2005 I-03875, para. 6; Case C-232/05, Commission of the European Communities v. French Republic (also known as 'Scott') (2006), I-10071, para. 2.

41 Joined Cases C-182/03 and C-217/03, Kingdom of Belgium (C-182/o3) and Forum 187 ASBL (C-217/o3) v. Commission of the European Communities (2006), 2006 I-05479, para. 147.

42 Case C-372/97, Italian Republic v. Commission of the European Communities (2004), 2004 I-03679, paragraphs 116-118; Council Regulation (EC) 659/1999, Article 15.

43 Case C-177/o6, Commission of the European Communities v. Kingdom of Spain (2007), 2007 I-07689, para. 46 and the case law cited therein.

44 Lufthansa (see Note 22), para. 30. Case C-354/90, Fédération nationale du commerce extérieur des produits alimentaires and Others $v$ France ('FNCE' in later notes) (1991), ECLI:EU:C:1991:440, para. 12. Please see also the document 'Commission notice on the enforcement of State aid law by national courts' (see Note 39), paragraphs 28-29.

45 Traghetti (see Note 28), para. 45.

46 Joined Cases C-6/90 and C-9/90, Francovich and Others (1991), 1991 I-05357.

47 Joined Cases C-46/93 and C-48/93, Brasserie du Pêcheur (1996), 1996 I-01029.

48 Konkurentsiseadus (CA' in later notes). - RT I 2001, 56, 332 (in Estonian), §42 (3). English text available at https://www. riigiteataja.ee/en/eli/519012015013/consolide/ (most recently accessed on 1.6.2015).

49 Riigivastutuse seadus. - RT I 2001, 47, 260 (in Estonian). English text available at https://www.riigiteataja.ee/en/ eli/515112013007/consolide/ (most recently accessed on 1.6.2015). 
The applicant may seek one of the following actions with the Estonian administrative courts: ${ }^{*} 5^{0} 1$ ) the full or partial annulment of the administrative act (annulment action) ${ }^{*} 51 ; 2$ ) the issuing of an administrative act or the taking of an administrative measure (mandatory action); 3) a prohibition to issue an administrative act or take a certain administrative measure (prohibition action); 4) compensation for harm caused in a public-law relationship (compensation action); 5) elimination of unlawful consequences of an administrative act or measure (reparation action); and 6) declaration of nullity of an administrative act, declaration of unlawfulness of an administrative act or measure, or declaration of ascertaining other facts of material importance in a public-law relationship (declaratory action). This article focuses on those actions that can be used to achieve the following: 1) recovery of unlawful aid along with illegality interest (annulment and reparation action); 2) interim measures, which can be submitted alongside other actions; ${ }^{*}{ }^{2}$ and 3 ) compensatory damages - compensation action.

The action is filed against the granting authority. According to Estonian law, the granting authority is the state, local-government, or other body (including a foundation, not-for-profit association, legal person in public law, or public undertaking) that directly or indirectly uses resources of the state or a local government for granting state aid. ${ }^{*} 3 \mathrm{~A}$ public undertaking is an undertaking over which the state or a local government exercises a dominant influence either directly or indirectly by virtue of right of ownership or financial participation, on the basis of the legislation applicable to the person or in any other manner. ${ }^{*} 54$

State aid may be granted in any of a variety of ways: issuing regulations ${ }^{*} 55$ or legislative acts of general application (e.g., the Estonian Electricity Market Act), entering into a contract under public law ${ }^{*} 56$, and issuing administrative acts ${ }^{*} 57$.

\subsection{Recovery of aid in Estonian administrative law}

\subsubsection{Aid granted on the basis of an administrative act}

If unlawful aid has been granted on the basis of an administrative act, the remedy for recovery of the unlawful aid would be to repeal the act. ${ }^{*} 8$ The consequence of repeal of an administrative act is that the unlawful aid is returned or, alternatively, compensated for in a manner pursuant to the relevant provisions of Estonian civil law. ${ }^{*} 59$ The beneficiary would have to return the aid after the court's decision. Where this is impossible, the granting authority will have an unjust-enrichment claim against the beneficiary, which only the granting authority may submit. ${ }^{* 60}$ In that case, the person may seek a reparation action to ensure the elimination of the unlawful consequences via ordering of the granting authority to reclaim the unlawful aid amounts. ${ }^{*} 61$ The court may, when a reparation action is filed for, order the granting authority to take all legitimate measures, including submitting claims to third parties. ${ }^{* 62}$

50 Halduskohtumenetluse seadustik (Estonian Code of Administrative Code Procedure) ('CACP' in later notes). - RT I, 23.03.2011, 3 (in Estonian), \$37 (2) 5). English text available at https://www.riigiteataja.ee/en/eli/509022015001/consolide/ (most recently accessed on 1.6.2015).

51 The CACP (\$37 (2) 1)) and SLA (\$3) use different terms for the same concept, for which reason 'annulment action' and 'action for repeal' are used synonymously in this article.

52 CACP, $§ 249(2)$

$53 \mathrm{CA}, \S 3 \mathrm{O}^{1}(1)$

54 CA, $\S 31\left(3^{1}\right)$

55 Haldusmenetluse seadus (Estonian Administrative Procedure Act) ['APA' in later notes]. - RT I, 2001, 58, 354 (in Estonian), §88. English text available at https://www.riigiteataja.ee/en/eli/509022015001/consolide/ (most recently accessed on 1.6.2015).

56 APA, §95.

57 APA, $\S 51$.

58 SLA, $\$ 3(1)$.

59 APA, $\S 69(1)$.

60 APA, §69 (1) and võlaõigusseadus (Estonian Law of Obligations Act). - RT I, 11.04.2014, 13 (in Estonian), §1028 (1). English text available at https://www.riigiteataja.ee/en/eli/516092014001/consolide (most recently accessed on 1.6.2015).

61 CACP, §37 (2) (5). Similarly, CCSCd 3-2-1-100-08, para. 27.

62 SLA, $\S 11(2)$. 
A person may generally claim for the repeal of an administrative act with an Estonian administrative court within 30 days after being notified of the act. ${ }^{*} 3$ If not receiving proper notification, the person may submit the claim within a reasonable period after obtaining information from an alternative channel about the administrative act granting the unlawful aid. ${ }^{*} 64$

Pursuant to Estonian law, the court may refuse the claim for repeal if it is filed significantly later than the notification sent to the addressee about the administrative act and repeal may violate the legitimate expectation of a third person. ${ }^{*} 65$ European Union state-aid law and the relevant case law of the ECJ do not recognise the possibility of refraining from recovering the aid in order to protect legitimate expectations of a third person. If that were the case in national proceedings, the court would have to ask for a preliminary ruling from the ECJ in order to interpret Article 108 (3) of the TFEU and ultimately determine the relevant provision's conformity with EU law.

Under Estonian law, the unlawfulness of an administrative act does not affect its validity. ${ }^{* 66}$ In cases of state aid, this provision could be problematic, since according to EU law, unlawful aid may not remain at the free disposal of the beneficiary. ${ }^{* 67}$ It follows that declaration of unlawfulness of the relevant administrative act is not a route that can yield results. The person instead has to claim for the repeal of the administrative act.

\subsubsection{Aid granted on the basis of a legislative act}

There are no special remedies in Estonian law that allow recovery of unlawful aid when the aid is granted on the basis of a legislative act. The SLA's §14 (1) allows the injured party to claim damages in this case. However, if the aid is disbursed through administrative acts that are based on that legislative act, recovery would be possible in accordance with the procedure described above. The current situation in Estonian law should be reviewed since Member States are obliged to implement procedural regulations effective for ensuring effective protection of individual rights conferred by Article 108 (3) of the TFEU ${ }^{*} 68$ and no clear remedies are available under the current provisions.

\subsubsection{Illegality interest}

A successful recovery claim results in the unlawful aid being recovered along with the illegality interest. ${ }^{* 69}$ If the Commission issued a positive decision but the aid measure was implemented before that decision, the unlawful aid does not have to be recovered unless national law allows this, but the obligation to pay the illegality interest remains. ${ }^{*} 70$ The illegality interest may be equated to the market interest accrued over the period of unlawfulness. ${ }^{*}{ }^{7}$

\subsection{Damage claims}

\subsubsection{EU law background applicable in Estonia}

Damage claims submitted on the basis of EU law must meet the following criteria: ${ }^{*} 72$ 1) the infringed provision confers rights on individuals, 2) the breach of the provision is sufficiently serious, 3) individuals have suffered damage, and 4) there is a direct causal link between the breach of the state's obligation and the damage suffered by the injured parties.

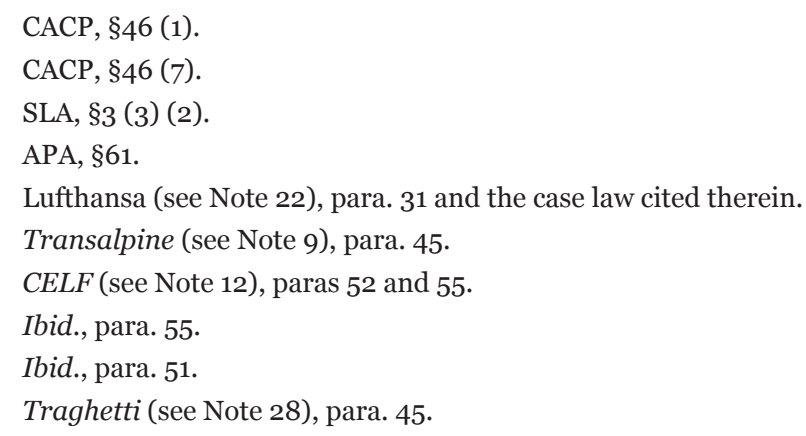


Breach of the standstill obligation is always considered to be a sufficiently serious violation because a Member State has no discretion in the matter and may not decide to implement state aid without first notifying the Commission or waiting for its decision. ${ }^{*} 73$ Where the state has no discretion, violation of the EU law provision may automatically establish sufficiently serious breach. ${ }^{*} 74$

It is up to the national court to establish a direct causal link between the breach of the state's obligations and the damages suffered by the injured parties. ${ }^{*} 75$ According to Estonian law ${ }^{*} 76$, such a link is established if the injured party is able to demonstrate that it would have avoided the damage had the state not failed in its obligations under Article 108 (3) TFEU.

A damage claim may still be an option where the Commission has declared state aid compatible with the internal market. One example involves the above-mentioned Estonian aid scheme subsidising renewableenergy producers. ${ }^{*} 77$ However, certain provisions of national law may restrict the possibility of claiming for damages, such as a time limit for bringing an action. ${ }^{*} 78$

\subsubsection{Estonian law}

While it is up to the Member State to decide on the procedure of submitting damage claims, the national law must still be consistent with the relevant provisions of EU law and the case law of the ECJ. The latter has been confirmed by the Supreme Court of Estonia, which has also ruled that a national law provision colliding with EU law must not be applied. ${ }^{*} 79$ This principle, implying the supremacy of EU law, has been affirmed by the ECJ ever since the Simmenthal case. ${ }^{*} 80$

Persons whose rights are violated by the unlawful activities of a public authority in a public-law relationship in Estonia may claim damages under the Estonian State Liability Act. Where unlawful state aid is granted via an administrative act, the injured parties may rely on §7 (1) of the SLA. Compensation for direct patrimonial damage and loss of income ${ }^{* 81}$ may be claimed if damage could not be prevented and cannot be eliminated by the protection or restoration of rights in the manner provided for in $\S \S 3,4$, and 6 of the SLA. It is most likely that persons harmed by unlawful state aid will claim for compensation for loss of income because the unlawful state aid would have improved the market position of the aid beneficiary to the detriment of the competitors.

If unlawful state aid has been granted on the basis of a legislative act, the injured parties must make their claims on the basis of the SLA's $\$ 14$ (1). This provision states that a person may claim compensation for damage caused by legislation of general application or by failure to issue such legislation only if the damage was caused by a significant violation of the obligations of a public authority, the legal provision forming the basis for the violated obligation is directly applicable, and the person belongs to a group of persons who have been specially injured through the legislation of general application or failure to issue such legislation. The last condition significantly restricts the number of persons able to claim compensation on the basis of the SLA's $\$ 14$ (1). As the condition runs counter to the relevant ECJ case law*82, it is not applied in cases wherein the standstill obligation is infringed.

Damage claims may be, in principle, satisfied if all the conditions set forth in $\$ 14$ (1) and §7 (1) of the SLA are met. The injured persons may claim direct patrimonial damages suffered as a result of a legislative act. This could also be the case with the unlawful aid scheme in Estonia that subsidised renewable-energy producers ${ }^{*} 83$, as end consumers were obliged to pay sums that the energy company had no right to invoice for before a positive decision of the Commission.

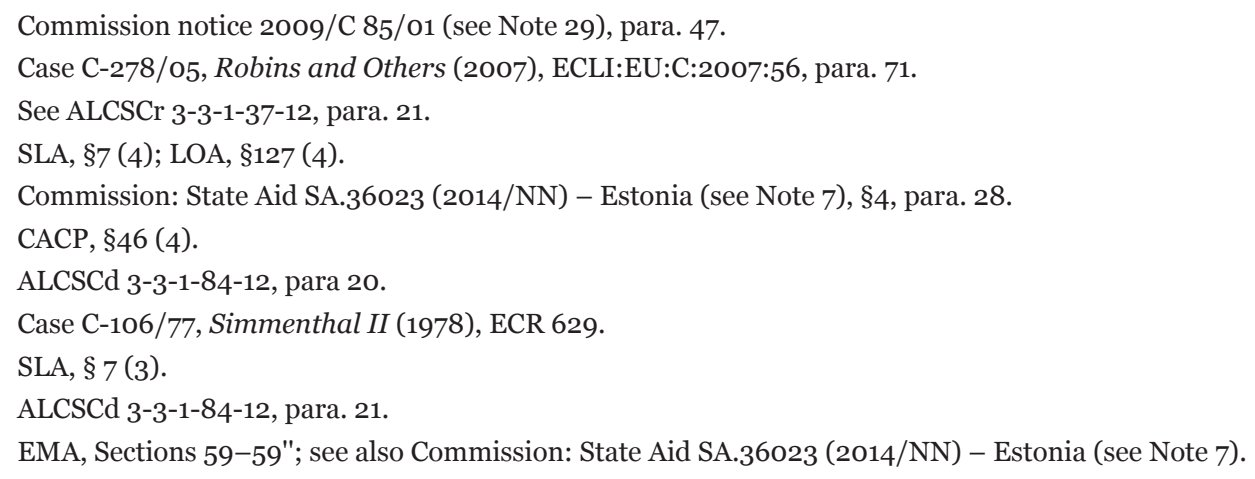


When processing claims submitted on the basis of the SLA's $\$ 14$ (1), the national court may reduce state liability pursuant to $\S 13$ of the SLA. This provision is applicable also in cases wherein EU law has been violated $^{*}{ }^{4}$. Estonian courts may limit the amount of compensation, taking into account the following: the extent to which the damage was unforeseeable; objective obstacles to preventing damage; the gravity of the violation of rights; limitations provided for in private law, regarding the part the injured party had in causing the damage; and other circumstances that would render compensation in full for the damage unfair. ${ }^{*}{ }^{5}$ The national provision also sets out the following criteria to specify when the national court is allowed to limit the amount of compensation:

- Loss of income is not compensated for if the person obliged to compensate for the damage proves that he is not at fault in causing the damage. ${ }^{* 86}$ This provision is in conflict with EU law, as the latter does not require the state's fault as a prerequisite for claiming damages that include loss of income. ${ }^{* 87}$ Therefore, this provision of Estonian law must be set aside.

- A public authority shall be relieved of liability for damage caused in the course of performance of public duties if the damage could not have been prevented even with full observance of the diligence necessary for the performance of public duties ${ }^{*} 88$. This provision would not be applied in state-aid cases, because there is no public duty to subsidise undertakings in breach of Article 107 (1) of the TFEU without informing the Commission in line with Article 108 (3) of the TFEU.

- An injured party who requests the elimination of consequences is required to incur the costs of elimination of consequences to the extent corresponding to the part the injured party had in causing the consequences. If, because the injured party cannot incur the costs corresponding to the part said party had in causing the damage, the consequences are not eliminated, then the injured party may request financial compensation corresponding to the share of liability of the public authority ${ }^{*} 8$. Such a situation might arise where the competitor was aware of the unlawful state aid but did not inform the authorities and incurred losses as a result of ongoing aid.

In addition, the state may, regardless of the request of the injured party, eliminate consequences connected to the matter by taking all lawful measures, including the issuing of administrative acts, taking of measures, and filing of claims in private law against third persons, if financial compensation would substantially exceed the costs of elimination of consequences and if the person does not have a good reason for claiming financial compensation. ${ }^{*} 90$ For example, the damage claims of the above-mentioned clients of Eesti Energia could be set off against their invoices.

\subsection{Interim measures}

There is no Estonian case law addressing interim measures used in situations involving state aid. However, the general principles underlying the application of interim measures could also be used in cases of state aid.

In the case law, it has been emphasised that the aim with interim measures is to prevent the situation of the claimant from worsening and to guarantee the execution of a court decision. ${ }^{*} 91$

The Code of Administrative Court Procedure states that when ruling on interim measures the court must consider public interests and the rights of the persons affected, alongside the prospects that the action entails, as well as the foreseeable consequences of the ruling for interim measures. ${ }^{*}{ }^{2}$

From examination of the relevant case law it becomes evident that the courts apply interim measures when the following criteria are fulfilled:

84 ALCSCd 3-3-1-37-12, para. 28.

85 SLA, $\$ 13(1)$.

86 SLA, $\$ 13$ (2).

87 Brasserie du Pêcheur (see Note 47), para. 51.

88 SLA, §13 (3).

89 SLA, $\S 13(4)$.

90 SLA, §11 (2)-(3).

91 ALCSCr 3-3-1-67-01, of 21.12.2001, Tõnu Kõrda. - RT III 2002, 4, 37 (in Estonian), para. 3.

92 Code of Administrative Court Procedure, §249 (3). 
- it is not highly unlikely that the claim will succeed ${ }^{*} 93$;

- there is a risk of irreversible consequences ${ }^{*} 94$;

- there is no significant public or third-party interest in non-application of the interim measure ${ }^{*} 95$; and

- the interim measure is proportional ${ }^{*} 96$.

The likelihood of the claim's success is a general prerequisite. The courts have explained that the application of an interim measure is, in essence, an advance assessment of whether the claim is founded or not. ${ }^{*} 97$ Since the decision on an interim measure must be taken as soon as possible, the court cannot conduct an extensive analysis of the likelihood of the claim being ultimately successful. The court makes an assessment of the prospects for the claim under limited conditions. ${ }^{*} 98$ Therefore, in a state-aid case, the competitor would have to substantiate with a degree of certainty that his right to fair competition has been infringed.

The risk of irreversible consequences is assessed in each individual case. Interim measures are applied where the applicant's rights would not be sufficiently protected even in the event of a favourable court decision. ${ }^{* 99}$ Alternatively, there is a need to apply an interim measure if the refusal to apply it would bring about burdensome consequences for the applicant and the elimination of these would be unreasonable ${ }^{* 100}$. In a state-aid case, the competitor would be able to rely on the risk of an irreversible consequence because the courts have regarded hampering the activity of a business as an irreversible consequence. ${ }^{*}{ }^{* 1}$ In cases involving state aid, the competitor could argue that the unlawful aid gives the beneficiary a more competitive position in the market and this consequence cannot be subsequently reversed.

There must not exist any significant public or third-party interest against the application of the interim measure. Significant public interest is present, for example, when it is necessary to carry out a public procurement in order to build a schoolhouse. ${ }^{*}{ }^{102}$ State aid may be given, inter alia, to projects of significant public interest. It is then the task of the courts to decide whether such interest outweighs the interests of the competitors of the beneficiary.

On the basis of the case law, it can be concluded that a competitor can successfully apply for interim measures in a state-aid case when the criteria described above are fulfilled.

\subsection{Preventing the payment of unlawful aid}

The above-mentioned argumentation could be effectively used to prohibit the issuing of an administrative act. A prohibition action is well founded if the rights of a person are at risk of being negatively affected. ${ }^{*} 103$ One can file for a prohibition action only if infringement of the competitor's rights has not yet taken place.

93 ALCSCr 3-3-1-76-04, of 22.11.2004, OÜ Kirderand. - RT III 2004, 34, 352 (in Estonian), para. 6; ALCSCr 3-3-1-85-04, of 14.12.2004, Toomas Raisi. - RT III 2005, 1, 1 (in Estonian), para. 16; Tartu Circuit Court ruling 3-15-27, of 29.1.2015 (in Estonian), para. 11; Tartu Circuit Court ruling 3-14-50421, of 13.5.2014 (in Estonian), para. 13; Tallinn Circuit Court ruling 3-14-50319, of 17.4.2014 (in Estonian), para. 19.

94 See, among materials from other authorities, Tallinn Administrative Court ruling 3-13-1665/4, of 6.8.2013 (in Estonian), para. 6.1; Tartu Circuit Court ruling 3-12-1936, of 31.10.2012 (in Estonian), para. 9; Tallinn Administrative Court ruling 3-14-50091, of 28.1.2014 (in Estonian), para. 3.1.

95 ALCSCr 3-3-1-67-01, of 21.12.2001, Tõnu Kõrda. - RT III 2002, 4, 37 (in Estonian), para. 1; ALCSCr 3-3-1-13-04 [of 8.4.2004]. - RT III 2004, 11, 130 (in Estonian), para. 19.

96 Tallinn Circuit Court ruling 3-14-50411, of 30.4.2014 (in Estonian), para. 12; Tallinn Circuit Court ruling 3-14-51996, of 12.9.2014 (in Estonian), para. 11; Tallinn Circuit Court ruling 3-14-50319, of 17.4.2014 (in Estonian), para. 19; Tallinn Circuit Court ruling 3-13-768, of 1.7.2013 (in Estonian), para. 14; Tallinn Administrative Court ruling 3-13-1665/4, of 6.8.2013 (in Estonian), para. 11; Tallinn Administrative Court ruling 3-13-1265, of 12.6.2013 (in Estonian), para. 9.

97 ALCSCr 3-3-1-17-04, of 17.6.2004, Eesti Haigekassa. - RT III 2004, 18, 213 (in Estonian), para. 30.

98 ALCSCr 3-3-1-76-04, of 22.11.2004, Ö̈ Kirderand. - RT III 2004, 34, 352 (in Estonian), para. 9; Tallinn Administrative Court ruling 3-13-1273, of 14.6.2013 (in Estonian); Tallinn Administrative Court ruling 3-13-1265, of 12.6.2013 (in Estonian), para. 12.

99 Tallinn Administrative Court ruling 3-14-50411/15, of 7.4.2014 (in Estonian), para. 8; Tallinn Circuit Court ruling 3-14-50411, of 30.4.2014 (in Estonian), para. 12; Tartu Circuit Court ruling 3-13-1960, of 7.11.2013 (in Estonian), para. 6.

100 Ibid.

101 Tartu Administrative Court ruling 3-12-1917, of 13.9.2012 (in Estonian), para. 7.

102 Tallinn Circuit Court ruling 3-14-51996, of 12.9.2014 (in Estonian), para. 12.

103 ALCSCr 3-3-1-84-11, of 19.6.2012, Aleksandr Šapovalov (in Estonian), para. 22; Tallinn Administrative Court ruling 3-13-198, of 5.2.2013 (in Estonian), para. 3.2; Tallinn Administrative Court ruling 3-14-51640, of 11.11.2014 (in Estonian), para. 16. 
Therefore, in a state-aid case a prohibition action could be used only before an administrative act is issued. After the issuing of an administrative act on the basis of which the beneficiary receives aid, a prohibition action loses its intended effect, since competition is distorted and therefore infringement of the competitor's right to fair competition has already taken place.

\section{Legal remedies in Estonian civil law}

State aid could also be granted through a civil transaction, such as a capital injection. In these situations, various civil-law remedies can be used by the competitors to the unlawful-aid beneficiary.

\subsection{Suspension of the implementation of the measure}

In a situation wherein there is potential of state aid being implemented, it is necessary to suspend implementation until the final decision of the Commission. Section 1055 (1) of the Estonian Law of Obligations Act (or 'LOA') provides a legal basis for said remedy. This provision forms part of tort law and allows the plaintiff to demand cessation of the action that is causing unlawful damage.

To demand the cessation of the action that is causing unlawful damage, the plaintiff must prove the following:

1) that the plaintiff has suffered damage due to the defendant's actions;

2) that the causing of damage is unlawful; and

3) that the causing of damage is ongoing.

The damage could be, for instance, loss of profit, which is named as a type of damage subject to compensation. ${ }^{*} 104$ As such, the loss need not entail harm to the person or property; it could be deemed a 'pure economic loss'. Under Estonian law, the tortfeasor is generally not liable for causing 'pure economic loss'. ${ }^{* 105}$ However, liability arises from the breach of a provision that is aimed at protecting the victim from such loss. ${ }^{*}{ }^{106}$ The Supreme Court has affirmed the liability arising from the breach of provisions of the Competition Act that are intended to protect fair competition. Considering that provisions prohibiting the granting of state aid have been designed in pursuit of the same goal, one can assume that they serve as a basis for liability for causing 'pure economic loss' to the competitors of the recipient of state aid. Therefore, declaring a competitor's loss of profit a 'pure economic loss' should not be an obstacle to the use of legal remedies under civil law.

The instances wherein the causing of damage is unlawful are enumerated in $\$ 1045$ (1) of the LOA. The only reason for unlawfulness is stated in point 7 of this section. According to the relevant provision, the causing of damage is unlawful if the cause constitutes a 'behaviour which violates a duty arising from law'. In the cases of state aid, the legal duty stems from Article 108 (3) of the TFEU.

Although a transaction can be finalised in a brief span of time, doing so does not put an end to the breach of the standstill obligation. As the ECJ found in the FNCE case, wherein unlawful aid was granted by a transaction, the validity of this transaction is affected ${ }^{* 107}$. A basis for declaring a transaction void is provided in $\S 87$ of the General Part of the Civil Code Act. The provision stipulates that a transaction is void if it is contrary to a prohibition arising from law and the purpose of that prohibition is to render the transaction void upon violation of the prohibition. Proceeding from the FNCE case, one could argue that Article 108 (3) of the TFEU does have such a purpose. The aid that has been received on the basis of a void transaction shall be returned pursuant to the provisions pertaining to unjust enrichment unless otherwise provided by law. ${ }^{* 108}$ Given that the Competition Act does not specify the procedure applicable in cases wherein there has been no Commission decision on the recovery, the provisions dealing with unjust enrichment are to be

104 LOA, $\S 128$ (4).

105 CCSCd 3-2-1-19-11, of 20.4.2011, para. 17.

106 Ibid.

107 FNCE (see Note 44), paras 12 and 18; Case C-390/98, Bank (2001), ECR I-6117, para. 73.

108 Tsiviilseadustiku üldosa seadus (General Part of the Civil Code Act). - RT I 2002, 35, 216 (in Estonian). English text available at https://www.riigiteataja.ee/en/eli/528032014002/consolide/ (most recently accessed on 24.3.2015). Section 87. 
applied. If aid is not recovered, the grantor's inactivity would continually cause damage to the competitors. Therefore, the competitor to the aid beneficiary could demand that the grantor recover the aid as means of suspending the damage-causing actions.

\subsection{Recovery of aid}

An obligation to recover unlawful aid is set forth in $\$ 42$ (3) of the Competition Act. Upon a decision of the European Commission or the ECJ ordering recovery, the grantor of the state aid must recover unlawful aid with the illegality interest. In contrast, the case law of the ECJ requires national courts to order aid recovery already when the Commission has initiated a formal investigation procedure and an action has been filed demanding recovery. ${ }^{*} 109$ Therefore, the national courts must not wait until the Commission issues its decision; they need to act upon the claim of the plaintiff. Any other interpretation of Article 108 (3) of the TFEU would make the aid available for use and endanger the functioning of the common market. Consequently, if Estonian courts were to rely only on the existing provisions of the Competition Act and not recover aid when the standstill obligation is breached, they would disregard the objective of the standstill obligation.

The necessary claim could be based on $\$ 1055$ (1) of the LOA. The Supreme Court of Estonia has ruled that this provision allows the plaintiff to demand termination of the negative consequences of the damaging acts. ${ }^{* 110}$ If the granting of the aid is to be regarded as the damaging act, the competitor could suffer negative consequences in the form of lost profit, which would be ongoing as long as the aid remains available to the beneficiary. The competitor may therefore demand the grantor of state aid to order recovery. As examined above, acts, including civil transactions, that entail the implementation of aid measures in breach of the standstill obligation are void ${ }^{*}{ }^{* 11}$ under Estonian law. This leads to the application of the provisions on unjust enrichment under Estonian law. If the grantor decides not to apply these provisions, the plaintiff can initiate an enforcement procedure to ensure that the unlawful aid is recovered from the recipient. In accordance with the case law of the ECJ, aid recovery must be ordered with the corresponding illegality interest. ${ }^{*}{ }^{112}$

\subsection{Damage claims}

Competitors of the aid beneficiary may incur losses because unlawful state aid renders the beneficiary more competitive. Whilst being a 'pure economic loss', such damage should be subject to compensation under Estonian law (see Subsection 4.1). The competitors would thus have a basis for a damage claim with the ECJ. Since Article 108 (3) of the TFEU is directly applicable, competitors may also claim damages on the basis of the case law of Francovich ${ }^{* 113}$ and Brasserie du Pêcheur ${ }^{* 114}$. The preconditions for damage claims have been analysed above.

Only actual and certain financial damage is subject to compensation. ${ }^{*} 115$ However, the European Commission has interpreted this notion quite broadly, including 'pure economic loss' among the damage subject to compensation. The claims of the competitor may encompass loss of the possibility of improving its asset position, loss of market share, or compensation for being forced out of business in consequence of unlawful state aid. ${ }^{*} 116$

The plaintiff must also ascertain the extent of the damage. This could prove problematic if the undertaking has suffered damages as a result of the breach of Article 108 (3) of the TFEU while also experiencing

109 Ibid., paras 69-70.

110 CCSCd 3-2-1-127-10, of 9.12.2010, Rein Kallaste v. Eesti Päevalehe AS, para. 11.

111 FNCE (see Note 44), paras 12 and 17; Case C-390/98, Bank (see Note 107), para. 73.

112 CELF (see Note 12), para. 54.

113 Francovich (see Note 46).

114 Brasserie du Pêcheur (see Note 47).

115 Enforcement of EU State aid law by national courts: The Enforcement Notice and other relevant materials. Brussels: European Commission 2010, para. 48. Text available at http://ec.europa.eu/competition/publications/state_aid/national_ courts_booklet_en.pdf (most recently accessed on 20.05.2015).

116 Ibid., para. 21. 
financial difficulties caused by other factors. In situations of this nature, professional appraisal might be necessary. Where the damage is established but the exact extent of the damage cannot be established, the amount of compensation shall be determined by the court. ${ }^{* 117}$

\subsection{Interim measures}

Probably the least clearly defined legal remedies that have been mentioned by the ECJ are the 'interim measures'. Irrespective of the nature of these measures, it follows from the case law of the Court that they must be effective enough to safeguard the interests of the individuals faced with violation of the standstill obligation. This objective could be achieved via various measures for securing an action, listed non-exhaustively in $\$ 378$ of the Estonian Code of Civil Procedure. Section 377 of the code allows the court to secure an action if there is reason to believe that failure to secure it may render enforcement of a court judgement difficult or impossible. Clearly, the aim behind these measures is to simplify the enforcement of the court decision. ${ }^{*} 118$

Whether the court actually employs any of the measures to secure an action depends largely on the claim. For instance, the court could prohibit the potential grantor from carrying out transactions related to the unlawful aid measure if the action to suspend the aid measure would not prevent disbursal of the aid in due time. ${ }^{*} 119$ On the other hand, the court may refuse to secure the action where it finds that the plaintiff would not have difficulties in receiving the damages.

\section{Conclusions}

According to the case law of the ECJ, it is up to the national courts to protect the rights of those individuals faced with breach of their rights derived from Article 108 (3) of the TFEU. The individuals most likely to be affected by violation of the standstill obligation are the competitors of the aid recipient. In order to guarantee the effectiveness of the standstill obligation and protect the rights of affected individuals, national law must prescribe legal measures that could remedy the violation of the standstill obligation. Remedies include suspension of the payment of unlawful aid, recovery thereof and interest thereon, awarding of damages, and interim measures. In Estonian law, possible measures are rooted in the State Liability Act and the Code of Administrative Court Procedure, under which potential aid is granted through an administrative act or measure, and the Law of Obligations Act, whereby aid measures are implemented through civil transactions. The most problematic aspect of the Estonian law affecting this matter is the absence of a sufficiently clear legal basis for ordering aid recovery prior to the Commission's decision. Recovery of aid could prove especially difficult in cases wherein aid has been granted on the basis of a legislative act. In consideration of the ECJ having indicated that Member States must provide such legal remedies, it is advisable that the Estonian legislator establish a clear provision for aid recovery prior to the Commission decision, preferably in the Competition Act, which contains provisions on state aid. The legislator could also review the State Liability Act, since this act establishes legal remedies to protect individuals against the state.

17 LOA, $§ 127(6)$.

118 CCSCd 3-2-1-30-11, of 11.5.2011, Aktsiaselts FRELOK v. OÜ SGA Production, para. 10.

119 Code of Civil Procedure, $\$ 378$ (1) 3). 